\title{
Pemerolehan Bahasa dan Penggunaan Bahasa Anak Usia Sekolah Dasar
}

\author{
Tri Mahajani*, Ruyatul Hilal Muhtar ${ }^{1)}$ \\ ${ }^{1)}$ Fakultas Keguruan dan Ilmu Pendidikan, Universitas Pakuan, Bogor, Indonesia \\ trimahayani68@yahoo.co.id
}

\begin{abstract}
The present study aims to examine a description of language acquisition and its usage by pupils in their daily conversations. This study employed a longitudinal case study and applieda descriptive method, while it used a content analysis for the research technique. The resultrevealed a finding upon the young learner language acquisition and its usage, the language acquisition included Bahasa Indonesia, Javanese language, Sundanese language and English language. The uses of language for a system, a personal expression, and an interpersonal expression were broad good enough and were uttered structurally, however, mistakes were founded on applying structures and making meaning to language in use. To pupils whom are at elementary school level, they have acquired a range of language structure and its use for perfection. Their parents, teachers, and their society have any real and valuable influence over them in the way language is structured and is used for exemplifying examples ofthe perfect language acquisition.
\end{abstract}

\begin{abstract}
Abstrak: Penelitian ini bertujuan untuk memperoleh deskripsi tentang pemerolehan dan penggunaan bahasa pada anak usia sekolah dasar dalam komunikasi sehari-hari. Penelitian ini menggunakan metode longitudinal case studi atau studi kasus longitudinal dan metode deskriptif, sedangkan teknik penelitian menggunakan teknik analitik isi. Hasil penelitian menunjukan bahwa pemerolehan dan penggunaan bahasa pada anak usia sekolah dasar terdapat pemerolehan bahasa Indonesia, Jawa, Sunda, Inggris. Penggunaan bahasa sebagai sebuah sistem, sebagai ungkapan personal, dan interpersonal sudah cukup baik dan sudah dapat menggunakan dalam struktur yang tepat, meskipun masih juga ditemukan kesalahan struktur dan makna pada penggunaan bahasanya. Pada anak usia sekolah dasar pemerolehan bahasa dan penggunaan bahasanya masih terus berkembang untuk mencapai kesempurnaan. Orang tua, guru, dan orang di lingkungan sekitarnya sangat berperan dalam membimbing dan selalu memberi masukan untuk mencapai kesempurnaan dalam pemerolehan dan penggunaan bahasanya.
\end{abstract}

Kata Kunci: Pemerolehan bahasa, Penggunaan bahasa, Language Acquisition Device.

\section{Pedahuluan}

Bahasa sebagai alat komunikasi dapat digunakan secara lisan maupun tulis. Setiap saat manusia menggunakan bahasanya untuk menghubungkan dirinya dengan dunia di luar dirinya. Menurut Pateda (1990), bahasa dapat dianalisis dari pendekatan: (a). bahasa sebagai suatu sistem; (b) bahasa sebagai tingkah laku personal; (c) bahasa sebagai tingkah laku antar personal.[1]

Bahasa sebagai sebuah sistem mempunyai kaidah-kaidah dalam pembentukannya. Kaidahkaidah itu itu berhubungan dengan pembentukannya dalam sruktur dan makna kalimat. Menurut Verhaar (2001) struktur adalah susunan bagian- bagian dalam dimensi linier [2]. Menurut Chaer (2000) kalimat adalah satuan bahasa yang berisi suatu pikiran atau amanat yang lengkap [3]. 
Bahasa juga sebagai tingkah laku personal. Sebagai tingkah laku personal, bahasa dapat diketahui dari tingkah laku penutur bahasa. Hubungan antara situasi, konteks verbal pembicaraan dapat dipelajari dan dapat diambil kesimpulan tentang makna yang terkandung di dalamnya. Selanjutnya, bahasa juga sebagai tingkah laku antar personal.Bahasa sebagai tingkah laku antar personal dapat dilihat melalui komunikasi pada situasi tertentu. Komponen yang menentukan berhasilnya komunikasi meliputi; (1) pembicara, (2) lawan bicara, (3) situasi. Apabila ketiga komponen itu berjalan dengan baik maka komunikasi akan lancar.

Pemakaian bahasa pada anak berhubungan dengan pemerolehan bahasa anak yang sangat dipengaruhi oleh lingkungannya. Dalam lingkungan keluarga, berapa banyak bahasa yang diajarkan orang tua pada anak, khususnya dalam komunikasi, itulah pemerolehan bahasa pada anak. Selain itu anak juga dapat memperoleh bahasa dari lingkungan sosial, seperti lingkungan, sekolah atau pergaulan dengan teman. Manusia, dalam hal ini anak, sejak lahir sudah dikaruniai bakat kemampuan berbahasa dengan adanya Language Acquisition Device (LAD) atau piranti pemerolehan bahasa (Chomsky dalam Hadley, 1993) [4].

Menurut Syamsul (2001), pemerolehan bahasa merupakan proses pemahaman dan proses hasil berbahasa pada manusia [5]. Faktor - faktor yang mempengaruhi pemerolehan bahasa anak meliputi :(1) keuniversalan bahasa; (2) perkembangan kognitif anak; (3) perkembangan sosial. Pemerolehan bahasa pertama dipengaruhi oleh faktor internal dan eksternal. Faktor internal berkaitan dengan faktor kognitif, Language Acquisition Device (LAD) atau perangkat pemerolehan bahasa yang dimiliki anak sejak lahir, serta IQ anak. Faktor eksternal meliputi lingungan sosial anak dan kesempurnaan masukan bahasa anak yang diperoleh dalam kehidupan sehari-hari. Pada pemerolehan bahasa pertama dan bahasa kedua anak akan berupaya dapat mencapai kompetensi dan perfomansi bahasa.

Selanjutnya Soenjono (2003) mengemukakan proses pemerolehan bahasa pada bidang Fonologi, Sintaksis, Leksikon, dan Pragmatik[6]. Pemerolehan bahasa pada tataran Fonologi berkaitan dengan bunyi-bunyi bahasa yang dihasilkan anak, seperti bunyi vokal dan konsonan. Misalnya, anak mengucapkan bunyi bahasa belum sempurna seperti contoh di bawah ini.

(1) papapa....mamama...bababa...

(2) Jam diucapkan / tam/ atau /dam/

(3)Eyang kakung diucapkan Eyang /tatung/

(4) Eyang putri diucapkan Eyang/putil

Pemerolehan bahasa anak pada tataran sintaksis dimulai dari pemerolehan satu, kata, dua kata, tiga kata atau lebih, dan pada akhirnya anak mampu merangkaikan kata dalam bentuk kalimat panjang seperti contoh berikut.

(5)mobil diucapkan anak /bi/ bisa dimaknai : Ma, itu mobil.

(6) Ayo lihat kupu-kupu diucapkan / liat tuputupu/

(7)Eyang kakung : Echa tadi nyuci sebelum masak atau sesudah masak.

Echa : Sesudah masak.

(8) Ibu, aku minta kue dong.

Pemerolehan bahasa pada tataran leksikon menyangkut kata-kata apa yang diperoleh anak pada awal ujurannya sangat ditentukan lingkungannya. Pemerolehan bahasa ini menganut prinsip sini dan kini yang universal. Artinya, di manapun juga kosa kata yang dikuasai anak pertama-tama adalah kosa kata dari objek yang ada di sekelilingnya (sini) dan yang saat itu ada (kini). Anak belum bisa membayangkan benda yang tidak ada atau peristiwa yang sudah atau belum terjadi. Misalnya, anak kota akan lebih mengenal kata-kata mobil, playstasion, komputer, radio, televisi dari pada anak desa. Anak desa akan lebih mengenal kata daun, rumput, cangkul, sawah, bebek dari pada anak kota. Dalam memnentukan makna kata anak cenderung mengikuti kaidah universal, misalnya dari bentuk, ukuran, objek, perluasan, peniruan, dsb.

Pemerolehan bahasa pada tatran pragmatik berkaitan dengan penggunaan bahasa dalam hubungannya dengan orang lain dalam masyarakat yang sama.

(9) Kamu mau pergi ke mana?

(10) Saudara mau pergi ke mana?

(11) Bapak mau pergi ke mana? 
Kalimat (9) dipakai oleh orang tua kepada anaknya, orang yang lebih tua kepada orang yang lebih muda. Pada kalimat (10) kata Saudara menunjukkan suasana yang renggang atau formal. Kalimat (11) kata Bapak bisa menunjukan hubungan atasan dengan bawahan. Pemerolehan bahasa dari segi pragmatik harus melihat aspek; (1) siapa yang diajak berbicara, (2) waktu kapan berbicara, (3) dengan siapa kita berbicara. Dalam lingkup pemakaian bahasa tertentu yang sangat memperhatikan sopan santun berbahasa, mis: bahasa Jawa, bahasa Sunda, anak harus diajari toto kromo. Dalam bahasa Jawa anak harus dapat membedakan pemakaian arep dan badhe, lungo dan tindak. Dalam bahasa Indonesia pemakaian pronomina kedua juga diatur oleh aturan sosial yang tidak sederhana, contoh: kamu, engkau, saudara, anda..

\section{Metode Penelitian}

Penelitian ini menggunakan metode longitudinal case studi atau studi kasus longitudinal dan metode deskriptif, sedangkan teknik penelitian menggunakan teknik analitik isi. Metode longitudinal case studi mengkhususkan pada subjek yang diteliti pada waktu tertentu, sedangkan metode deskriptif digunakan untuk menggambarkan sifat suatu keadaan yang sementara berjalan pada saat penelitian. Teknik analisis isi digunakan untuk menganalisis pemerolehan dan penggunaan bahasa dalam sebuah struktur kalimat.

Penelitian ini dilakukan pada seorang anak, Farah Difa, yang berusia delapan tahun, usia sekolah dasar. Sedari kecil Farah memperoleh dua bahasa secara bersamaan yaitu bahasa Indonesia dan Jawa, dari Ayah (A), Ibu (I), Kakak (Yajid), dan memperoleh bahasa lain dari lingkungannya. Pengumpulan data dilakukan dengan cara mencatat data. Pencatatan dikhususkan pada pemerolehan dan penggunaan bahasa yang digunakan bersamaan dalam sebuah struktur kalimat. Data yang terkumpul kemudian dianalisis dilihat dari pemerolehan bahasa dan penggunaan bahasa sebagai sistem, bahasa sebagai ungkapan personal, dan penggunaan bahasa antar personal.

\section{Hasil dan Pembahasan}

Pemerolehan dan penggunaan bahasa dilihat dari segi bahasa sebagai sistem, bahasa sebagai ungkapan personal, dan bahasa antar personal. Bahasa sebagai sistem dilihat dari struktur juga makna penggunaan dua bahasa yang dipakai secara bersamaan dalam sebuah struktur kalimat, Farah memperoleh bahasa Indonesia, bahasa Jawa, juga bahasa Sunda, dan bahasa Cina. Dalam penggunaannya sudah mampu memadukan beberapa bahasa dalam struktur kalimat tetapi masih belum tahu kaidah pemakaiannya.

Pemerolehan dan penggunaan bahasa sebagai ungkapan personal, Farah memperoleh bahasa Indonenesia juga bahasa Jawa. Dalam penggunaannya Farah banyak menggunakan bahasa Indonesia, sedikit menggunakan bahasa daerah untuk ungkapan personalnya. Sebagai ungkapan antar personal, Farah memperoleh bahasa Indonesia dan bahasa Jawa. Penggunaan bahasa Jawa masih terasa belum merperhatikan kesopansantunan karena farah belum mengetahui aturan pemilihan kata sopan santun dalam bahasa Jawa. Berikut pembahasan pemerolehan dan penggunaan bahasa Farah.

\section{1) Pemerolehan dan Penggunaan Dua Bahasa sebagai Sebuah Sistem}

Bahasa sebagai sistem berkaitan dengan struktur dan makna penggunaan dua bahasa dalam sebuah struktur kalimat, yaitu bahasa Indonesia dan bahasa Jawa. Berdasarkan penganalisis data, ternyata dalam membentuk struktur kalimat, berupa wacana, Farah selalu menggunakan dua bahasa. Meskipun Farah belum tahu betul aturan penggunaan masing-masing bahasa tetapi dia sudah dapat memadukan pemakaian dua bahasa tersebut dalam sebuah sruktur kalimat. Walaupun, masih ditemukan juga kesalahan memadukan ke dua bahasa tersebut. Berikut analisis pemakaian stuktur dan makna dua bahasa yang benar.

$$
\begin{aligned}
& \text { Y : Wolu likur itu apa to Farah? } \\
& \mathrm{F}: \text { Ya ampun, emas nggak tahu wolu likur to! } \\
& \text { (Ya ampun, mas tidak tahu dua puluh delapan to.) } \\
& \mathrm{T} \quad \text { : Cepetan sini Farah! }
\end{aligned}
$$




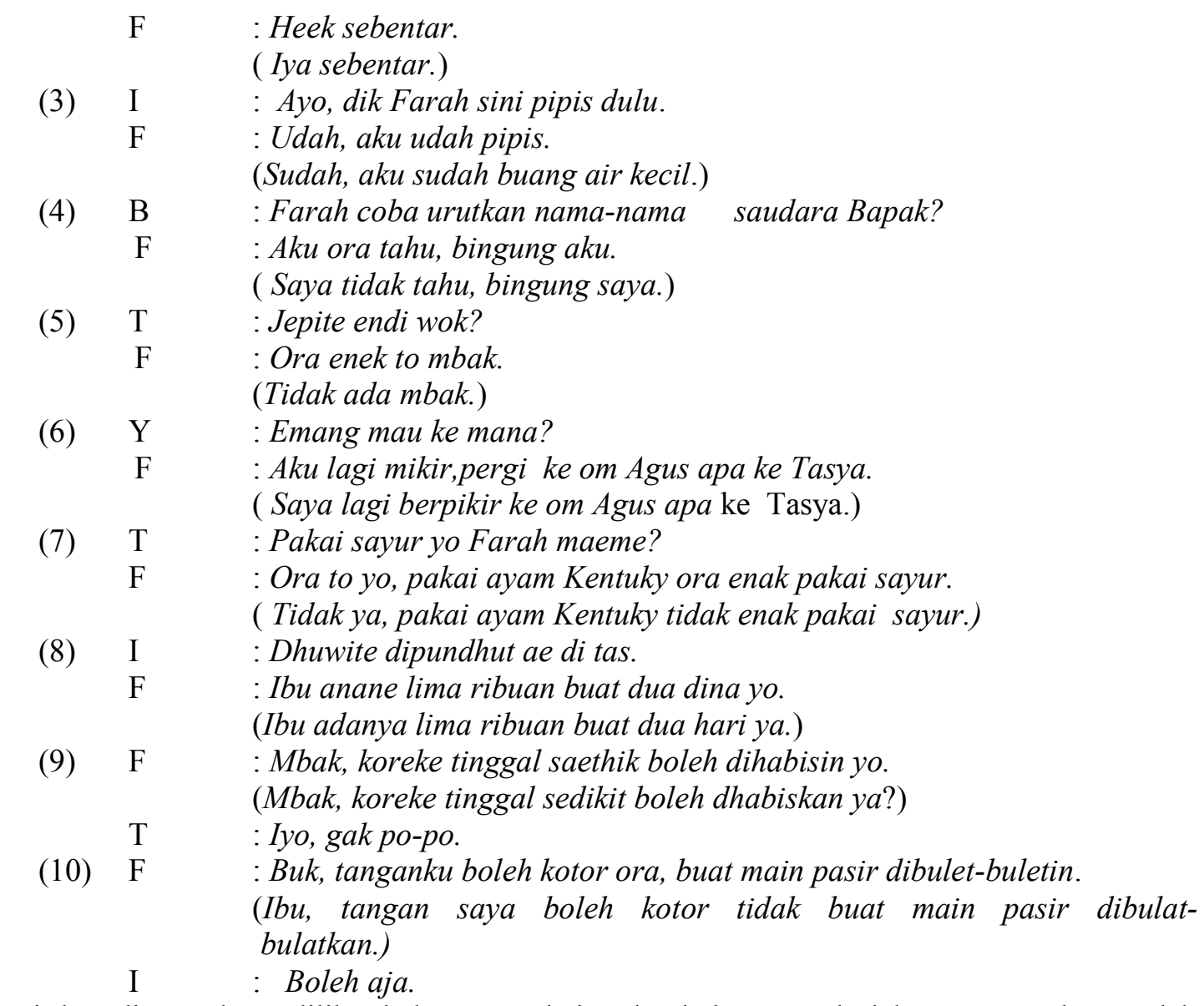

Dari data di atas dapat dilihat bahwa pemakaian dua bahasa Farah dalam satu struktur sudah tepat. Artinya, dia sudah dapat memasukan bahasa kedua untuk penyesuaian struktur dengan bahasa pertama. Farah mampu menempatkan posisi pokok pembicaraan atau pelaku perbuatan, perbuatan, sasaran perbuatan, dan keterangan keseluruhan kalimat sehingga pemakaian dua bahasa itu berterima struktur dan maknanya. Walaupun sebenarnya, pemakaian bahasa yang bercampur dalam sebuah stuktur kalimat menyalahi aturan yang ada.

Pada kasus Farah, dari kecil dia memperoleh dan menggunakan dua bahasa secara bersamaan dari lingkungan keluarga. Dari hasil pengamatan dialog dapat dianalisis bahwa tanpa sadar semua anggota keluarga dalam komunikasi mencampuadukan dua bahasa tersebut, sehingga Farah mencampuradukan pemakaian dua bahasa tersebut karena mencontoh anggota kelurga. Pemakaian yang terus menerus akhirnya membuat dia mampu membentuk struktur kalimat untuk kemudahan komunikasi.

Seperti pada kalimat (1) Ya ampun, mas nggak tahu wolu likur to! Farah sudah dapat membentuk sebuah kalimat seru dengan urutan struktur yang benar, yaitu Ya ampun sebagai seruan, mas sebagai pokok pembicaraan, nggak tau sebagai verba, wolu likur sebagai penjelas verba. Kalimat (2) muncul pemakaian kata heek yang berarti iya, merupakan pemakaian ungkapan dalam bahasa Jawa untuk keenakan berkomunikasi dan maknanya berterima. Pada kalimat (3) muncul bentuk berulang udah yang terletak di depan verba pipis, artinya kencing, untuk penekanan makna bahwa dia betul-betul sudah pipis.Pemakaian kata sudah pun sudah mengalami pemendekan menjadi udah untuk keenakan komunikasi. Farah sudah dapat menggabungkan dua buah kalimat Aku ora tau, artinya aku tidak tau, dan bingung aku, artinya bingung saya menjadi kalimat majemuk yang maknanya berterima seperti kalimat (4) Aku ora tau, bingung aku. Selain itu, Farah juga membentuk kalimat inversi bingung aku merupakan penginversian dari aku bingung. Pada kalimat (5) Ora enek to mbak. merupakan pembentukan kalimat struktur bahasa Jawa penuh, yang artinya tidak ada mbak. Pemakaian bentuk to pada sruktur itu sebagai penekanan makna. 
Kemampuan Farah membentuk struktur majemuk bermakna dengan pelesapan unsur juga terlihat pada kalimat (6) dan (7). Tiga buah kalimat Aku lagi mikir, pergi ke om Agus, pergi ke Tasya digabungkan menjadi Aku lagi mikir, pergi ke om Agus atau ke Tasya. Terdapat pelesapan unsur pergi pada ke Tasya. Struktur Ora to yo, ayam Kentuky ora enak pakai sayur. Terdapat pelesapan unsur ayam Kentuky dan penekanan makna kalimta dengan munculnya bentuk to. Pada kalimat (8) dan (9) muncul anane, yang artinya adanya, pada Ibu anane lima ribuan, buat dua hari yo. Bentuk koreke, yang artinya koreknya, terlihat ada pembentukan bermakna kata berakhiran ne dan $e$ pada bahasa Jawa, meskipun jarang sekali ada pada pembentukan kata-kata farah. Pemakaian akhiran in dan bulet pada dibulet-buletin terpengaruh oleh bahasa prokem anak-anak terlihat pada kalimat (10) buat main pasir dibulat-buletin.

Selanjutnya akan dianalisis kesalahan pemakaian bahasa dilihat dari sruktur dan makna pada bahasa yang digunakan Farah. Kesalahan pemakaian dapat dilihat pada sruktur kalimat berikut.
(11) I : Ibu masih ngetik.
F : : Ngetik satu bab seharian, itu namanya kesuwen, ibu tidak lama.
(12) I $\quad$ :Dik Farah kok dadi item.
( Ngetik satu bab seharian, itu terlalu lama, ibu tidak lama.)
F $\quad$ : Ibu gosong gitu, putihan aku to gosong-gosong kene.
(13) I $\quad$ : Ibu hangus gitu, putih
F $\quad$ : Ibu aku pusing po? tapi aku ora bilang
(14) I $\quad$ : Ibu aku pusing apa, tetapi
F : : Rambute ora iso disisiri to, gondrong-gondrong.
$\begin{array}{ll}\text { (15) F } & \text { : Tulisane kok paling teraneh ki. } \\ & \text { (Tulisannya paling teraneh nih) }\end{array}$
(Rambutnya tidak bisa disisir, panjang-panjang.)
Y : Biarin.

Pada kalimat (11) penggunaan kalimat tersebut kurang tepat baik dari segi struktur ataupun makna. Kesalahan pada struktur itu namanya kesuwen dan ibu tidak lama, struktur dan makna tidak berhubungan. Kalimat (12) pemakaian kata gosong yang berarti hangus kurang tepat untuk memaknai kulit yang hangus, apalagi dibentuk menjadi perulangan gosong-gosong, yang berarti hangus-hangus. Hanya pada kalimat ini sepertinya Farah menggunakan kata itu untuk membentuk kata yang metaforis. Kalau kata itu dihubungkan dengan kemetaforisan bahasa maka maknanya bisa berterima. Pada kalimat (13) Ibu aku pusing po? Tapi ora bilang. Makna kalimat pada struktur yang dibuatnya kurang tepat karena Ibu aku pusing po? merupakan kalimat pertanyaan yang memerlukan jawaban, sedangkan kalimat selanjutnya tapi ora bilang merupakan pernyataan yang seolah-olah sudah benar bahwa dia pusing. Struktur dan makna kalimat (14) Rambute ora iso disisiri to, gondrong-gondrong juga membawa kerancuan makna karena yang dimaksud rambutnya yang sudah panjang sehingga susah untuk disisir. Kesalahan makna juga terjadi pada kalimat (15) Tulisanne kok paling teraneh ki. Tulisannya aneh memaknainya tulisannya itu jelek sekali, jelek dipadankan dengan bentuk lain aneh. Pemakaian paling dan ter mengalami redudansi yaitu pemakaian struktur yang berlebihan karena ter pada aneh sudah berarti paling.

Dari hasil analisis ditemukan, Farah juga memakai kata bahasa Sunda dan bahasa Inggris dalam struktur kalimatnya. Itu terdapat pada kalimat berikut.
(16) B
: Enak sekali pijitan Farah
F :Ini mah pijitan ala Farah dan bik Kusum.
(17) $\begin{aligned} & \mathrm{Y} \\ & \mathrm{F}\end{aligned}$
( Ini pijatan model dik Farah dan bik Kusum)
: Tungguin bentar Farah.
: Maaf mas, pesawat udah take off.
(Maaf mas, pesawat dah siap berangkat)
(18) F :Mas buka pintu, lagi ngapain, what ?
(Mas buka pintu, lagi ngapain, apa?)
Y
: Ntar aja ah. 
(19) T : Ini mukenanya Farah.

F : : Naruh aja di situ, no problem.

(Naruh aja di situ, tidak masalah.)

Pada kalimat (16), (17) pemakaian kalimat secara struktur dan makna sudah tepat. Kalimat (16) muncul ungkapan sunda mah yang tidak bermakna, hanya untuk keenakan berbicara. Pada kalimat(17) muncul kata bahasa inggris take off yang bermakna siap terbang. Pada kalimat (18) dan (19) pemakaian srtuktur dan makna kalimat mengalami kesalahan. Kalimat (18) mas buka pintu, lagi ngapain, what? Kata what pada struktur akhir kalimat kurang tepat karena what bermakna apa sehingga kurang berkesinambungan dengan srtutur dan makna Mas lagi buka pintu, lagi ngapain. Kalimat (19) pemakaian kata bahasa Inggris no problem sudah tepat, kesalahan terletak pada kata naruh seharusnya taruh, sehingga bentuk tersebut menjadi Taruh aja di situ.

\section{2) Pemerolehan dan Penggunaan Dua Bahasa sebagai Ungkapan Personal}

Dari hasil pengamatan dan analisisis data yang ditemukan pada pemerolehan dan penggunaan bahasa Farah, ternyata untuk ungkapan personal, Farah jarang memakai dua bahasa Indonesia dan bahasa Jawa. Perasaan-perasaan ungkapan personal Farah lebih banyak diwujudkan dalam bahasa Indonesia dan sedikit sekali pencampuradukan bahasa Jawa. Ungkapan personal dalam analisis ini dikhususkan pada penggunaan bahasa monolog Farah. Farah mengungkapkan kegembiraan, kesenangan, kesedihan, kekesalan, dan kemarahan dalam bentuk monolog. Monolog yang dilakukan sambil beraktivitas melakukan sesuatu. Penggunaan bahasa sebagai ungkapan personal terlihat pada bentuk berikut.

(20) (Sambil bermain boneka, Farah bercerita sendiri.)

Ini bapaknya sama ibuk pakai baju bagus ya, anaknya nanti ganti juga. Cantik nih ntar pergi ke pesta, seneng deh orang padha cantik. Kita nanti minum es krim ya.

(21) (Pulang sekolah Farah kesal karena nunggu jemputannya lama.)

Sebel, sebel, om Kuya jemputnya kelamaan jadinya aku capek. Ibuk sih nggak bilang sama om Kuya, dimarahin gitu biar nggak telat lagi, sebel.

(22) (Farah baru saja telpun bapaknya, ada berita bapak malam ini pulang.)

Asyik-asyik, bapak pulang.. bawa roti, bawa mainan, emas enggak.Jam berapa ya nyampai rumah. Ibuk...aku tidurnya nunggu bapakya.

(23) (Farah kesal ketika membuka dompetnya uangnya nggak ada lima ribu)

Dompetku mbukak sih, siapa yang ngambil uangku, pasti mas. Sebel, pasti emas, awas kalau mas pulang uangnya aku minta lima ribu.

(24) ( Farah pulang sekolah, nggak tau ibu ada di lantai atas.)

Mbak, Ibu, kok sepi padha ke mana..? Mbak...(nggak ada jawaban) ibu tadi katanya nungguin aku, nggak kerja, ninggalin aku deh.. katanya mau ngajak aku jalan-jalan.

Pada kalimat (20) sambil bermain boneka, Farah bercerita sendiri mengungkapkan kesenangan hatinya dalam kalimat Ini bapaknya sama ibuk pakai baju bagus ya, anaknya nanti ganti juga. Cantik nih ntar pergi ke pesta, seneng deh orang padha cantik. Kita nanti minum es krim ya. Farah mengungkapkan kesenangan hatinya dengan menggunakan bahasa Indonesia, sedikit sekali kata bahasa Jawa yang digunakan secara bersamaan, hanya pada kata Ibu dan padha. Banyak gaya santai berbahasa, seperti cantik nih, ntar pergi ke pesta. Yang menarik pada ungkapan personal tersebut adalah keterlibatan farah pada permainan boneka seolah-olah dia berada dalam cerita tersebut. Dia senang bersama-sama boneka khayalannya.

Pada kalimat (21) pulang sekolah Farah kesal karena nunggu jemputannya lama. Dia mengungkapkan kekesalannya dalam struktur Sebel, sebel, om Kuya jemputnya kelamaan jadinya aku capek, capek. Ibuk sih nggak bilang sama om Kuya, dimarahin gitu biar nggak telat lagi, sebel. Penggunaan ungkapan bahasa Jawa telat dipakai pada pengungkapan kemarahan yang semuanya diungkapkan dalam bahasa Indonesia. Farah mengungkapkan kemarahan dengan mengulang bentuk sebel dan capek pada bentukan kalimatnya. Ini menggambarkan emosi kemarahannya pada om Kuya yang telat menjemput dengan cara mengungkapkannya dalam bentuk 
monolog. Ini menggambarkan emosi anak kecil yang akhirnya menyalahkan pada ibunya seolaholah ibu tidak mau menolongnya dengan cara menegur om Kuya.

Kegembiraan terungkap ketika Farah baru saja telpun bapaknya, ada berita Bapak malam ini pulang. Bapaknya sudah tiga hari dinas di Surabaya sehingga tidak bertemu. Mungkin sudah rindu sama Bapak sehingga muncul kegembiraan, nampak pada ungkapannya pada kalimat (22) Asyikasyik, bapak pulang.. bawa roti, bawa mainan, emas enggak. Jam berapa ya nyampai rumah. Ibuk...aku tidurnya nunggu bapak ya. Ungkapan kegembiraan itu semua diwujudkannya dalam struktur kalimat bahasa Indonesia. Hanya masih muncul sifat egoismenya anak kecil terungkap pada perilaku yang tidak akan mau ngasih kakaknya roti dan mainan oleh-oleh dari Bapak.

Pada kalimat (23) Farah kesal ketika membuka dompetnya uangnya nggak ada lima ribu. Kekesalannya diungkapkan dengan langsung menuduh kakaknya, tampak pada ungkapan. Perilaku anak kecil yang masih perlu dibimbing orang tua, karena kita tidak boleh menuduh orang sembarangan. Dompetku mbukak sih, siapa yang ngambil uangku, pasti mas. Sebel, pasti emas, awas kalau mas pulang uangnya aku minta lima ribu. Ungkapan bahasa Jawa muncul pada kata mbukak.

Kesedihan Farah tampak ketika Farah pulang sekolah, dia tidak tau ibu ada di lantai atas. Farah pulang sekolah rumah dalam keadaan sepi karena mbaknya lagi keluar rumah. Memanggilmanggil tidak ada yang memberikan jawaban. Dia perasaannya sedih karena tadi Ibu sudah berjanji menunggu Farah pulang dan mengajaknya pergi. Ungkapan perasaan itu terungkap pada struktur kalimat Mbak, Ibuk, kok sepi padha ke mana..? Mbak...(nggak ada jawaban) ibu tadi katanya nungguin aku, nggak kerja, ninggalin aku deh.. katanya mau ngajak aku jalan-jalan. Pemilihan ungkapan bahasa jawa hanya pada bentuk padha, semua srtuktur untuk mengungkapkan kesedihan memakai kata bahasa Indonesia.

\section{3) Pemerolehan dan Penggunaan Dua Bahasa sebagai Ungkapan Antar Personal}

Penggunaan bahasa sebagai ungkapan antar personal ini melibatkan pembicara dan pendengar, maksud pembicara, dan kesopansantunan berbicara. Analisis penggunaan dua bahasa sebagai ungkapan antar personal ini lebih mengfokuskan pada kesopansantunan atau unggah-ungguh berbahasa. Hal itu terlihat pada data kalimat berikut.

(25) I $\quad:$ Ayo sini, sinau dik Farah.

F : : : $\quad$ mboke istirahat anake suruh belajar, ora adil namanya.

(26) F :Bapak jorok belum mandi, ambune ora enak.

(Bapak kotor belum mandi, baunya tidak enak.)

B : Enak aja, udah juga.

(27) F : Minta sangunya dong pak!

( Minta uang sakunya dong pak)

B : Seribu aja.

F : Bapak sama ibu sama-sama pelit, ora ana gunane.

(Bapak sama ibu sama-sama kikir, tidak ada gunanya)

(28) I : Tunggu dhisik dik Farah!.

F : Walah ibu itu, aku udah ke kamar, nakal kowe.

(Walah ibu itu, saya sudah ke kamar, nakal kamu.)

(29) I : Apaan sih!

F : Ibu itu ora mikir kaya mas ae.

( Ibu itu tidak berpikir seperti kakak aja.)

(30) F : Wah ibu, bikin karasehan di sini, piye to iki.

(Wah ibu buat keributan di sini.)

I : Huss, nggak pareng.

Berdasarkan pengamatan dan analisis data dapat diketahui bahwa dalam ungkapan yang berwujud dialog Farah banyak menggunakan, mencampuradukan dua bahasa Indonesia dan Jawa dalam satu struktur kalimat. Dilihat penggunaan bahasa berdasarkan hubungan antar personal, 
Farah banyak melakukan kesalahan penggunaan, terutama bahasa Jawa. Hal tersebut terjadi karena dia belum tahu betul penggunaan sopan santun atau tata krama dalam bahasa Jawa. Sebenarnya orang tua sudah sering mengingatkan dan membetulkan kesalahan berbahasanya, tetapi mungkin disebabkan pemerolehan bahasa Farah masih berkembang terus. Selain itu ketidakformalan hubungan orang tua dengan anak juga berpengaruh pada kesalahan berbahasanya.

Pada kalimat (25) Emboke istirahat anakke suruh belajar merupakan ungkapan yang kasar orang tua pada anak. Kata embok dan anak sebenarnya biasa hanya ditambah e menjadi emboke dan anakke menunjukan kemarahan anak pada orang tua. Unggah- ungguh dalam masyarakat Jawa bahwa anak itu harus menuruti perkataan orang tua dan tidak boleh membantah apalagi mengucapkan perkataan kasar. Pada kalimat (26) Bapak jorok belum mandi, ambune ora enak merupakan pelanggaran aturan sopan santun atau toto kromo anak pada orang tua.Jorok itu berarti kotor dan ambune berarti baunya, merupakan bahasa Jawa kasar. Karena ungkapan itu kasar maka tidak boleh digunakan anak untuk mengungkapkan sesuatu pada orang tuanya. Apabila kata itu diungkapkan pada orang yang lebih muda ke orang yang lebih tua akan mempunyai konotasi tidak enak pada pendengar. Kata itu boleh digunakan hanya untuk orang tua pada anak atau anak-anak yang umurnya sebaya.

Bapak ibu dua-duanya sama-sama pelit, ora ana gunane. Kalimat (27) tersebut juga merupakan pemakaian yang kasar. Kata-kata kasar banyak digunakan Farah pada penggunaan bahasa Jawanya, dan tidak ada penggunaan kasar pada kata bahasa Indonesia. Dia belum mengerti sopan santun berbahasa Jawa jadi masih menggabungkan,mencampuradukan begitu saja dengan bahasa Indonesia. Kata pelit berarti kikir, ungkapan kikir merupakan bahasa yang kasar. Oleh karena itu pembicara yang lebih tua, yang lebih muda, ataupun sebaya tidak boleh mengungkapkan maksud dengan kata pelit, apalagi ungkapan berbahasa anak pada orang tua. Demikian juga pada kalimat (28) nakal kowe. Kowe yang berarti kamu merupakan ungkapan untuk orang kedua bersifat kasar dan rendah dalam pemakaian. Nakal biasa digunakan untuk orang tua pada anaknya. Jadi apabila kowe dan nakal dipakai oleh anak pada orang tua maka anak tidak menghargai dan merendahkan martabat orang tua.

Kalimat (29) mikir pada Ibu itu ora mikir kaya mas ae, mempunyai sopan santun rendah. Mikir yang maksud pembicara berpikir menjadi rendah maknanya karena disejajarkan dengan mikir dalam bahasa Jawa. Demikian juga kalimat (30) karesehan juga diasumsikan sebagai keributan. Jadi ada unsur anak menasehati orang tua jangan membuat keributan. Sementara pada budaya Jawa biasanya orang tua yang menasehati anak, bukan anak yang menasehati orang tua. Apabila anak menasehati orang tua dibilangnya tidak sopan.

\section{Kesimpulan}

Pemerolehan dan penggunaan bahasa sehari-hari, Farah, anak usia sekolah dasar, meliputi pemerolehan dan penggunaan bahasa sebagai sebuah sistem, bahasa sebagai ungkapan personal, bahasa sebagai ungkapan antar personal. Pemerolehan bahasa meliputi bahasa Indonesia dan Jawa, terdapat juga beberapa kata bahasa Sunda dan bahasa Inggris. Pemerolehan bahasa banyak diperoleh dari keluarga dan lingkungan sekitarnya.

Penggunaan dua bahasa sebagai sistem terdapat bahasa Indonesia dan bahasa Jawa yang dipakai bersamaan dalam sebuah kalimat. Penggunaan bahasa sehari-hari sudah cukup baik dan sudah dapat menggunakan dalam struktur yang tepat, meskipun masih ditemukan kesalahan struktur dan makna pada penggunaan bahasanya. Ditemukan juga penggunaan kata bahasa Sunda dan bahasa Inggris. Penggunaan dua bahasa sebagai ungkapan personal lebih banyak menggunakan bahasa Indonesia. Hampir semua struktur dan makna diungkapkan dengan menggunakan bahasa Indonesia, sedikit sekali penggunaan bahasa Jawa. Ungkapan monolog untuk mengungkapkan perasaan personalnya, meliputi perasaan kegembiraan, kesenangan, kekesalan, kesedihan, dan kemarahan. Penggunaan dua bahasa sebagai ungkapan antar personal menunjukan bahwa penggunaan bahasa Indonesia tidak banyak kesalahan, kesalahan banyak terdapat pada pilihan kata bahasa Jawa. Pilihan kata yang menyatakan unggah-ungguh atau sopan santun dalam bahasa Jawa banyak yang belum tepat karena anak belum tahu aturan pilihan kata kesopanan dalam bahasa Jawa. 
Pemerolehan bahasa dan penggunaan bahasa anak usia sekolah dasar pada Farah masih terus berkembang. Oleh karena itu orang tua, guru, dan orang di sekitarnya sangat berperan dalam membimbing dan selalu memberi masukan untuk mencapai kesempurnaan dalam pemerolehan dan penggunaan bahasanya.

\section{Referensi}

[1] Pateda, Mansoer. 2007. Aspek-aspek Psikolinguistik. Ende Flores. Nusa Indah

[2] Verhaar. 2001. Asas-Azas linguistik Umum. Yogyakarta. Gadjah Mada University Press.

[3] Chaer, Abdul. 2000. Tata Bahasa Praktis Bahasa Indonesia. Jakarta. Rineka Cipta.

[4] Hadley, Alice Omaggio. 1993. Teaching Language 2 Edition. Heinle and Heinle. USA

[5] Sodiq, Syamsul. 2001. Psikolinguistik. Universitas Terbuka.

[6] Dardjowidjojo, Soenjono. 2003. Psikolinguitik. Jakarta. Yayasan Obor Indonesia. 